\title{
Brothers of the Pure Sinhala Fraternity
}

"By my reading, anticolonial nationalism creates its own domain of sovereignty within colonial society well before it begins its political battle with the imperial power," writes Partha Chatterjee in The Nation and Its Fragments: Colonial and Postcolonial Histories. Before persons form anticolonial political movements, native intellectuals carve out unique spaces that Chatterjee designates the "inner domain." The inner domain is a realm of authentic culture that native intellectuals imagine to remain untouched by colonialism. ${ }^{1}$ One of the main contributions of Chatterjee's theory is the way it assigns a new starting place-cultural reform-for conventional histories of colonial-era nationalism, histories that customarily begin with narratives about anticolonial movements and battle with the imperial power.

I accept the premise of the inner domain but disagree with the emphasis Chatterjee places on intellectuals of colonized nations who create inner domains in relation to Western hegemony. Chatterjee focuses on Bengali cultural nationalism and its complex interaction with Western culture. But he considers Bengal, the metropolis of the British Raj, to be representative of colonized nations. ${ }^{2}$ In this chapter I continue to explore the colonial period but focus on an alternative school of scholars, poets, and songwriters to reveal how one cultural movement in Sri Lanka sought to define the nation, not in relation to the West but in opposition to North India.

THE LINGUISTIC PURISM OF MUNIDASA

CUMARATUNGA

By the early twentieth century, native elites throughout South Asia had begun to consider their language as a spiritually unifying marker of cultural identity. As 
early as 1891 Maratha nationalist B. G. Tilak campaigned to redraw boundaries of an independent India along linguistic lines. In 1920 Mahatma Gandhi acceded his support to create linguistic provinces for an independent India. ${ }^{3}$

Linguistic politics united the community but violently divided self from other. Although Hindi and Urdu are structurally the same, when South Asia's postcolonial era erupted with the 1947 partition of India, the devanägari script for Hindi and the nasta'liq script for Urdu helped justify the creation of separate Hindu (India) and Muslim (Pakistan) nations. ${ }^{4}$ Many additional language crusades followed in South Asia, including the Bengali Language Movement of 1952, fasts-until-death for a separate Telugu state in 1951-52, Sinhalese mob attacks in retaliation to Tamil resistance to the 1956 Sinhala Only language act, Fateh Singh's fast-until-death in 1960 for a Punjabi-speaking state, agitations that divided the Bombay State along linguistic lines into Gujarat and Maharashtra, and Tamil riots in 1965 to protest against Hindi as the official language of India.

The modern history of linguistic politics in Sri Lanka begins with Munidasa Cumaratunga. Between 1922 and 1944 Cumaratunga sought to do for the Sinhala language what the revivalists had attempted to accomplish for the Buddhist religion. Cumaratunga believed that reforming, uplifting, and fostering loyalty for the Sinhala language would help bring independence to the Sri Lankan nation. ${ }^{5}$

Integral to his project was the fight for linguistic purism. Cumaratunga wanted Sinhala writers to reject all nonnative lexical items when using the native language. E. Annamalai writes that linguistic purism is caused by the "redefinition of power relations when the social order is undergoing change." In Cumaratunga's case, one can add that linguistic purism can influence societal change. His purist project to remove Sanskrit and Pali influence from the Sinhala language was an integral aspect of his efforts to construct a new school of cultural nationalism that challenged the dominance of the Arya-Sinhala camp.

In 1922 Cumaratunga resigned from his position as an inspector of AngloVernacular schools for the Department of Education. Between 1922 and 1942 he reconstructed classical works of Sinhala verse and prose. The Department of Education approved these texts, twenty-eight in total, to be used for public exami-

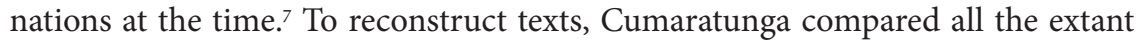
manuscripts of a work and rewrote lines to achieve what he believed to be the original, authentic, and "pure" version. His work reconstructing texts gave him expertise in morphology, syntax, parsing, lexical choice, phraseology, and orthography of authors and manuscript scribes. This expertise would help him later fashion a pure Sinhala linguistic register-one rid of not only Sanskrit and Pali but also Portuguese, Tamil, and English loanwords, as well as Sinhala colloquialisms. ${ }^{8}$ During the period he reconstructed Sinhala texts he also published weekly editorials in his newspaper Lak Mini Pahana (The gem light of Lanka) that campaigned to standardize Sinhala grammar, urged Sinhalese politicians to speak in their 
mother tongue (rather than English), and advocated that Sinhala grammar should be taught with the rigor in which English teachers taught English to Sri Lankans. ${ }^{9}$

The purist ideologies Cumaratunga brought to the study of Sinhala literature are evident in the introduction he wrote for his commentary on the twelfth- or eleventh-century work known as the Muvadevdāvata (Account of the Makhādeva Jātaka):

\begin{abstract}
Although there are many poems composed in Sinhala, Sinhalese people consider the most important to be Sasadāvata [Account of the Sasa Jātaka], Kavsilumiña [Crestgem of poetry], and Muvadevdāvata [Account of the Makhādeva Jātaka]. The poetic diction in these works is chaste because Sinhalese poets composed these works before the [twelfth-century treatise on Sinhala grammar known as the] Sidatsañgarāva and therefore did not employ the "five transpositions" or use rhyme in two or three places in the lines of quatrains. ... Errors of ignorant scribes have corrupted these works and impeded literary appreciation.... Scholars [like myself] who reconstruct these texts can easily tell which errors are because of a lapse or inadvertence. We have considered it appropriate, in the interest of young scholars, to produce a pure text of this poem as best we can. ${ }^{10}$
\end{abstract}

In this excerpt Cumaratunga listed three factors that he believed determined whether poetic diction was corrupt. First, it was corrupt if the linguistic register had been subject to the "five transpositions"-five types of diachronic linguistic change (modification in vowels, letters, words, case, and verbal conjugation) described in the twelfth-century treatise on Sinhala grammar, the Sidatsañgarâva. It was also corrupt if there was an excessive use of eli väta, the poetic technique whereby the final syllable in each line of the quatrain ended with a like-phoneme. Finally, it was corrupt if there were "errors resulting from the lapses of ignorant scribes," which referred to linguistic confusions, omissions, and additions, such as the mix-up of similar letters, misinterpretation of contractions, errors in translating words of general resemblance, wrong word combinations or punctuation, or substitutions of synonyms. ${ }^{11}$

George Thomas outlines an eight-stage process that language reformers often use to "purify" languages. "Recognition of need" and "identification of targets" are the first two stages. ${ }^{12}$ One can say that Cumaratunga both recognized the need to purify the language found in various manuscripts of the Muvadevdàvata and identified fixable targets to produce a "pure text" of the poem.

One can see later stages in the purification process in an article Cumaratunga authored that sparked a literary debate that came to be known as the Kukavi Vädaya, or "Poetasters Debate." The debate was published in the journal Swadéśamitrayā (Friend of the nation) between June 1925 and December 1927.

Out of the entire corpus of Sinhala poetry, the three works Muvadevdâvata, Sasadàvata, and Kavsilumina are the flowers at the summit. . . The soft words in 
Muvadevdàvata are charming but its author had plundered meanings from the great Sanskrit poets. We do not, therefore, bestow great respect on this work. . . In the Sasadāvata there are several places influenced by Sanskrit verse, yet these instances have only shadows of the Sanskrit words, not the exact copies. Shadows appear but the poetic diction is not corrupt. As it is said: [Sanskrit] "The poet imitates the shadow of another poet's meanings. The poetaster takes the meanings. The thief takes the words." 13

That Cumaratunga's language ideologies were opposed to the Arya-Sinhala preference for Sanskrit-heavy Sinhala is evident in Cumaratunga's judgment that unmodified Sanskrit loanwords corrupted the poetic diction of pure Sinhala. He praised the same three works mentioned in the first excerpt of this section. Yet here he placed the Sasadāvata on a higher literary plane than the Muvadevdàvata because the Sasadàvata contained many Sanskrit "shadows," or tadbhavas, which are modified Sanskrit cognates that retain a Sinhala flavor. They are different from tatsamas, unmodified Sanskrit loanwords that Cumaratunga believed corrupted Sinhala.

Cumaratunga then alleged that Toṭagāmuve Śrī Rāhula (1408-91) did not deserve the title of "poet" because his masterwork, the Kāvyaśêkhara (Crown of poetry), was heavy in Sanskrit tatsamas: "The scholar who catches thieves with their stolen goods are criticized for having a crooked mouth. ... Most Sinhalese scholars consider the Kävyaśêkhara more distinguished than other classical poems. However, according to the Sanskrit phrase above, the author of the Kävyaśêkhara does not deserve the title of "poet." ${ }^{14}$ Challenging the worth of the Kāvyaśékhara was controversial. The Sinhalese intelligentsia held Śrī Rāhula’s works in the utmost esteem. When Cumaratunga wrote in the excerpt, "The scholar who catches thieves with their stolen goods are criticized for having a crooked mouth," he was referring to himself as the "scholar who catches thieves," and Toṭagāmuve Śrī Rāhula, author of Kāvyaśékhara, as the thief. The "stolen goods" was a reference to the Sanskrit tatsamas Śrī Rāhula used in Kāvyaśékhara. Cumaratunga was criticized for having a "crooked mouth" because he idiosyncratically filled his writings with the ä-käraya, the third letter of the Sinhala alphabet, which makes a "crooked" vowel sound like the "a" in "cat" pronounced in an American accent.

Cumaratunga believed that the ä-kāraya was the "purest" indigenous letter in the Sinhala language since it does not exist in practically any other South Asian language. He revered Guruḷugōmi's twelfth-century Amāvatura (Ambrosial water)a narrative of incidents in the Buddha's life-because Gurulugōmi heavily used the ä-kāraya letter and favored Sanskrit tadbhavas over tatsamas, which gave his poetic diction a distinctive hela, or "pure," Sinhala flavor. ${ }^{15}$ Cumaratunga and his followers suffixed the ä-kāraya letter onto nouns to convey the genitive case, verbs for past participles, and prepositions to create emphatic and predication markers. ${ }^{16}$ 


\section{DECONSTRUCTING ARYA}

In 1941 Cumaratunga established the Hela Havula (Pure Sinhala Fraternity), an organization that aimed to promote the Sinhala language and reform its modern grammar according to the linguistic register found in Sinhala literature created between the twelfth and seventeenth centuries. Cumaratunga and his colleagues in the Hela Havula conceived of an alternative identity to the Arya-Sinhala model. One of Cumaratunga's closest colleagues in the Hela Havula was the poet Rapiyel Tennakoon (1899-1965), who deconstructed the Arya-Sinhala identity in an article he published in the Helio in 1941, titled "The Hidden History of the Helese":

What a shame for us Helese, to have a section of our own countrymen who believe that they are the descendents of a gang of barbarian's robbers [Prince Vijaya and his retinue] from the Lata country! According to the Island-chronicles [such as the Mahāvamsa] the leader of this gang of robbers was a grandson of a highway robber who lived in a cave in the great forest region then known as 'lata vanaya' in South Guzarat $[s i c] . .$. Their ships, dispersed by the storm, lost their way in the open sea. Some of them, including the one in which the leader of the gang was on board, reached the island of the Helese. The crew, worn out by hunger and thirst, landed on the shore behind the jungle district, well known all over the ancient commercial world by the [ancient] name of [Sri Lanka,] Tommanna. ${ }^{17}$

Here Tennakoon challenged the heroic portrayals of Prince Vijaya championed by the Arya-Sinhala revivalists, disgraced Vijaya as a leader of a gang of barbarous robbers, rejected the belief that the Sinhalese were descendants of Vijaya, and suggested that the Sinhalese (the "Helese") were already on the island when Vijaya and his retinue arrived.

Tennakoon also attempted to deconstruct the Arya-Sinhala identity by critically tracing the term Arya in scholarly discourse:

According to our modern writers, these Vadakkayas [Harassers] [sic] were the first Aryan settlers of the Helese island. I do not know what they mean by the word "Aryan." The Buddhist literature says that "Aryans" are those who had attained to the noble eight-fold path. But we cannot believe that our modern writers mean the same sin-proof holy beings by the recently coined word Aryan.

The scholars who wanted to mention all the groups of the northern band of the fair-skinned human race in the world as a single family used the word Aryan, which is a word coined very recently in a German mint without taking into consideration that the very same name existed in ancient Indian literature to express quite a different meaning. But soon they saw that the word Aryan did not give a wider sense than that given by the ancient word "ariya." As the scope they wanted to cover by the meaning of the word Aryan grew wider they felt the want of a new word for the purpose. Then the scholars began to use the newly coined compound word Indo-Aryan. This new treatment made the patient more ill instead of curing him, for ancient "Aryans" were especially Indians. Then the scholars coined another compound word 
"Indo-Germanic" to give a still wider sense than that given by the former one. But the meaning they wanted to express by that word began to spread beyond its circle. ${ }^{18}$

"German mint" most likely referred to Max Müller's popularization of the concept of the "Arya" race. This idea fed into German linguist Wilhelm Geiger's widely praised linguistic studies $(1897,1899)$ that established the Sinhala language's IndoAryan roots. Geiger's linguistic categorization of Indo-Aryan further established the belief that the origins of the Sinhalese were North Indian, a belief shared by the Arya-Sinhala nationalists but fought against by the members of the Hela Havula.

\section{CUMARATUNGA'S HELAA MİYÄSIYA}

In 1942 Cumaratunga published Hela Mìnäsiya (Sinhala music). He intended to publish three additional volumes that treated rhythm and Sinhalese percussion instruments, but he passed away in 1944 at the age of fifty-three. Hela Mìyäsiya was a violin self-study manual, a collection of patriotic lyrics Cumaratunga wrote in the purist Sinhala, and a treatise that created theoretical foundations for a national system of music based on the singing of Sinhala poetry.

Thomas delineates two types of linguistic purism. "Offensive purism" attempts to force a radical departure from traditional usage. "Defensive purism" strives to stop the use of undesirable development. ${ }^{19}$ Cumaratunga's post-1939 diction, which commenced with his publication of the Subasa (Good language) journal and was in full form in Hela Mìyäsiya, was of the "offensive" type. It radically departed from common usage in the way it removed unmodified Sanskrit, Pali, English, Tamil, and Portuguese loanwords; employed the ä-kāraya; and introduced idiosyncratic purist replacements.

Thomas defines "replacement" as the provision of an acceptable alternative to undesirable linguistic elements. ${ }^{20}$ Replacement is the sixth stage in Thomas's language purification process. The word miyäsiya, found in the book's title, is one such replacement. Cumaratunga coined the term as an alternative for sangita, the Sanskrit word for "music." Mi- means sweet or pleasant, and -äsiya denotes something heard, thus mīyäsiya literally means "sweet sound." ${ }^{21}$ In his introduction to Hela Mìyäsiya Cumaratunga ridiculed the Sinhalese composers who studied classical music in North India and thought little of Sinhala music traditions: "When you mention 'Hela music,' a large group gathers around. These are the people who have studied singing and instrumental music in North India. They scoff, 'What vocal music do the Sinhalese have? What instrumental music? Sinhalese singing is like the lament we hear at funerals. What is Sinhalese instrumental music except the unpleasant thunderous sound of the bera drum [the traditional Sinhalese double-headed drum] that should be removed from the temple on Poya [the Buddhist holidays that occur on a full moon day] and even from hell itself!'” ${ }_{22}$ 
Cumaratunga also criticized composers who imitated the style of the first Asian Nobel laureate, Rabindranath Tagore: "Another shameful thing they do is to compose songs in the style of people like Rabindranath Tagore. What do our composers do? They listen to this type of song and imitate its meter and words and then trick all the foolish people who swoon." ${ }^{23}$ Because Cumaratunga desired to free Sri Lanka from Indian cultural influence, he bestowed new Sinhala-language names onto the standard Indian terms for musical notes (sa, re, ga, ma, pa, da, ni). He designated the seven natural notes as si, ri, gi, mi, pi, di, ni and the sharp fourth as $m u$, and he used his favorite letter the ä-kāraya to name the flat second, third,

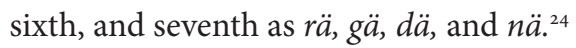

Cumaratunga's critique of Sinhalese composers who believed in the superiority of North Indian music was connected to his attempt to reinterpret the Mahàvamsa, which claimed that the Sinhalese were originally from North India. As stated earlier, according to the chronicle, the Sinhalese had descended from the North Indian prince Vijaya in the fifth century B.C.E. Cumaratunga argued that the real roots of the Sinhalese were with the "Helas," the indigenous islanders whom Vijaya conquered. Yet Cumaratunga also looked to the Mahāvamsa chronicle for evidence of an ancient Sinhalese musical tradition untouched by India. He wrote this in the introduction to Hela Mìyäsiya: "After covering the Hela girl traitor named Kuveni with a cloth, Vijaya, the leader of the thieves, crept closer to the Hela abode. What were the Helas doing? They were pleasing their minds with singing, playing, and dancing. One would think Vijaya's heart softened from hearing such sweetness. But the Helas danced, sang, and played instruments not knowing that Vijaya would soon murder them." ${ }^{25}$ Cumaratunga here referred to an episode narrated in the Mahâvamsa: Prince Vijaya could conquer the indigenous islanders because Kuveni the Hela queen betrayed her own kin, the "Helas." After spending a night with Kuveni, Vijaya heard sounds of music and singing foreign to him. He asked, "What does this noise mean?" Kuveni replied that the music was for a seven-day Hela wedding festival taking place in the city Sirisavatthu. ${ }^{26}$ Vijaya and his retinue then went to Sirisavatthu, vanquished the Helas, and began to rule ancient Lanka. Cumaratunga believed that this very story in the Mahāvamsa gave evidence of an indigenous Sinhalese musical tradition.

Many of Cumaratunga's songs in Hela Mìyäsiya expressed the slogans of the Hela Havula. For example, this song lyric championed Cumaratunga's "triple gem" campaign that valorized the Sinhala country, nation, and language:

For any country, except my country, the Hela country

For any nation, except my nation, the Hela nation

For any language, except my language,

I will never bow my head, I will never bow my head ${ }^{27}$

In the early twentieth century the motto of Arya-Sinhala nationalism had been "country, nation, and religion." Cumaratunga replaced religion with language. 
Sandagomi Coperahewa writes that this replacement "reflects the growing importance of the language factor in Sinhala nationalism and politics in the late $1930{ }^{2} .{ }^{28}$ Indeed, between 1932 and 1942 Sinhalese politicians presented resolutions to the State Council to use Sinhala and Tamil, rather than English, in debates of the council and in the administration of justice.

Although Cumaratunga had no contact with the reformers of music and language in Tamil Nadu, his interpretation of Sinhalese origins, ideologies of linguistic purism, and musicological treatise paralleled the contemporaneous language and music movements in Tamil Nadu. Cumaratunga's conviction that the Sinhalese were not descendants of North Indians but originally indigenous islanders of Lanka inspired him to rename the Indian musical tones with Sinhala note names. Similarly, a pioneer of the Tamil music movement, Abraham Pandithar (1859-1919), created a body of exclusively Tamil music theory. Pandithar's music theory was based on his belief in the existence of the lost continent of Lemuria, wherefrom all Tamil speakers were said to have originated. ${ }^{29}$

Further, both Cumaratunga and the founder of the Tamil purist movement, Maraimalai Adigal (1876-1950), rejected their respective ethnic groups' putative Aryan roots. They based this refutation on what they believed to be the inherent uniqueness of the Tamil and Sinhala languages and each language's autonomy from Sanskrit. Both Cumaratunga and Adigal were not of high caste. One may infer that their positions as rural elites and to some degree "subalterns" in relation to the high castes affected their outlook in some way. Cumaratunga, however, did not publicly seek to empower the lower castes, as Adigal did in his Non-Brahmin Manifesto. ${ }^{30}$

Despite these commonalities between music and language reform in Sri Lanka and Tamil Nadu, the Sinhalese and Sri Lankan-Tamils became increasingly polarized within Sri Lanka in the 1940s. Tamil culture had deeply influenced early twentieth-century Sinhala gramophone music, nineteenth-century Sinhala drama (nādagam), and eighteenth-century Sinhala court song (vannama). Yet exclusory language policies in Sri Lanka in the 1940s began to create a conspicuous lack of cultural dialogue between the Sinhalese and the Tamils in Sri Lanka and India. In 1943, a year before Cumaratunga passed away, Sinhalese politicians enacted the first resolution to make Sinhala the only official language of the state.

From a wider vantage point, one might consider Cumaratunga's language loyalty as a Sri Lankan case of the large-scale shift in South Asia from language-asmedium to language-as-marker of ethnic identity. Sumathi Ramaswamy and Lisa Mitchell detail the way the Tamil and Telugu languages of South India came to constitute a defining characteristic of Tamil and Telugu individuals in the twentieth century. ${ }^{31}$ Like the Tamil and Telugu language reformers whose campaigns contributed to this shift, Cumaratunga created a unique inner domain of Sinhalese ethnic identity with the Sinhala language at its heart. 
Through the organization of the Hela Havula and publications like Hela Miyäsiya, Cumaratunga impressed on poets and songwriters the importance of his purist project of reform. The task of the remainder of this chapter is to come to terms with the way in which Cumaratunga exerted influence on the poetry of Rapiyel Tennakoon and songs of Sunil Santha, two members of the Hela Havula.

\section{BAT LANGUAGE}

In 1927 Cumaratunga was appointed principal of the teacher's training college in Nittambuwe. There he befriended Rapiyel Tennakoon, the history and geography instructor. ${ }^{32}$ Tennakoon joined Cumaratunga's Hela Havula in 1942 and presided as president between 1949 and $1965 .{ }^{33}$ Tennakoon read Cumaratunga's Virit Väkiya (Treatise on Sinhala poetic meters, 1938) and began to compose verse in the metered style prescribed by this book. ${ }^{34}$ In two years Tennakoon had completed eleven long-metered poems, four of which comprised more than one thousand quatrains apiece.

Impressed, Cumaratunga published three of Tennakoon's long poems for $\mathrm{Cu}$ maratunga's book series Ruvan Väla (Chain of gems). Cumaratunga used the Ruvan Väla series to exclusively publish poetry by members of the Hela Havula. The series had commenced in 1936 with Cumaratunga's autobiographical long poem Piya Samara (Remembering Father). Tennakoon's poems were satirical and polemical. In Hävilla (The curse, 1940), he lampooned zealous religious practices, and in Dä Vinaya (Discipline of the nation, 1941) he satirized corrupt politics. ${ }^{35}$

The poetry written by members of the Hela Havula diverged in three ways from the style of the first-generation Colombo poets. First, the Hela Havula poets wrote in an erudite literary language that bordered on cryptic, a style that radically deviated from the easily understandable language of the Colombo poets. Second, they used a more expanded repertoire of meters. The Colombo poets wrote mostly sivpada (quatrains), with end-rhyme (eli väta) and an equal amount of mātrā (syllabic instants) per line. Yet Tennakoon favored $g \bar{\imath}$ meters, quatrains with uneven amounts of mātrā. ${ }^{36} G \bar{\imath}$ was a meter common to Sinhala poetic works composed between the twelfth and seventeenth century, like the Sasadāvata, Muvadevdā, and Kavsilumina. Because Tennakoon, along with his brothers in the Hela Havula, held these literary works in esteem, he was inclined to use gi meters. Third, Hela Havula poets appended commentaries onto their works of poetry. The Colombo poets did not append commentaries on their poems because the common reader could understand the meaning. Detailed exegesis, by contrast, was necessary for the Hela Havula poets, since they employed an arcane lexicon and commented on myths, current events, and biographical details through slight allusions, some of which could seem like inside jokes. 


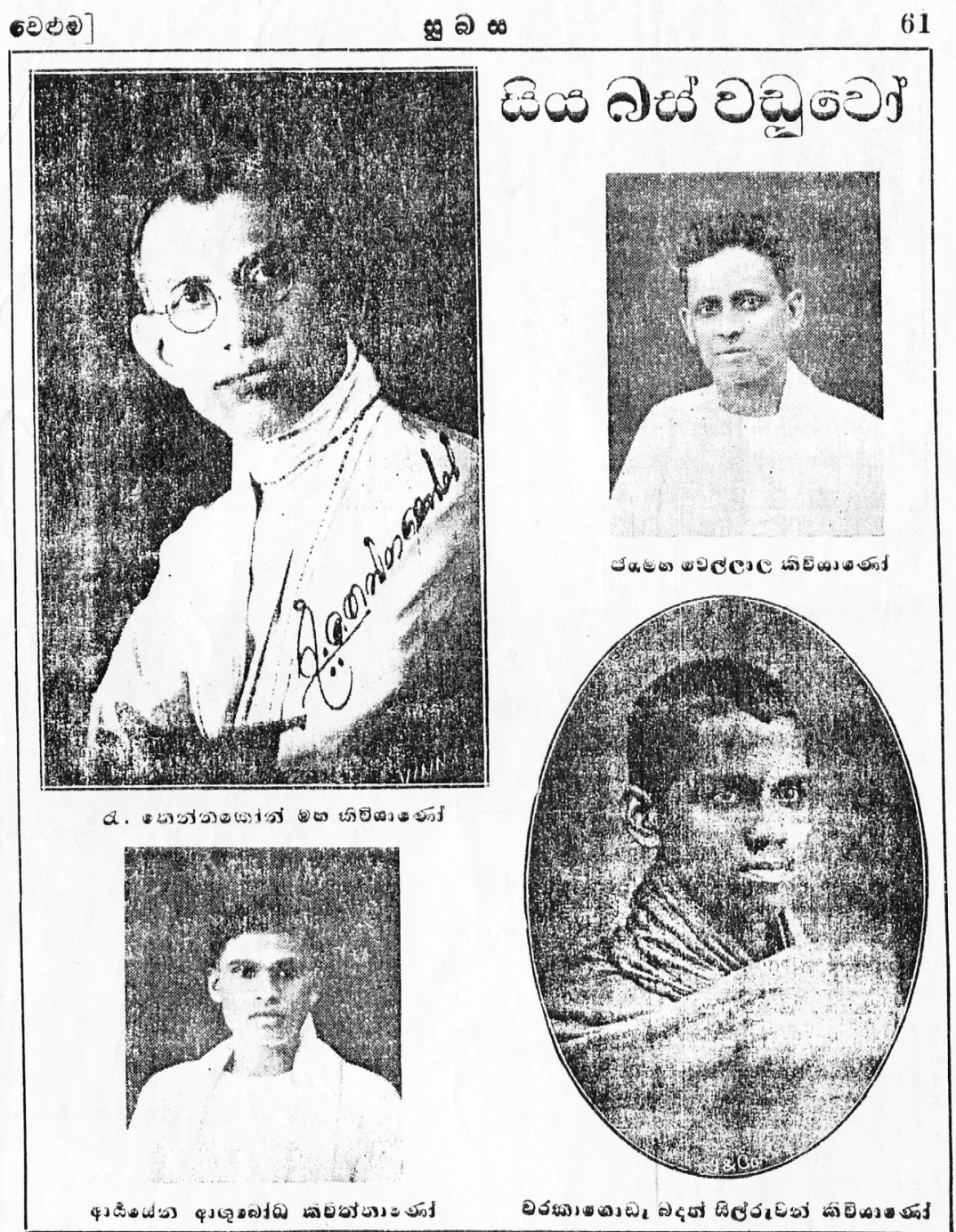

FIGURE 2. "Siya Bas Vaḍuvō" (Developers of the native language), Subasa (1941): 61. Clockwise from top left: Rapiyel Tennakoon, Jayamaha Vellala, Ven. Warakagoda Silruwan, and Aryasena Anshuboda (who later changed his name to "Arisen Ahubudu"). 
The Hela Havula poets, some of whose pictures were featured in a 1941 issue of Cumaratunga's Subasa (fig. 2), adopted for their exegesis the precise format that Sinhala literary scholars used to interpret classical Sinhala literature. In the anvaya (word order), the commentator put the quatrain into sentence syntax. In the vistara or padyartha (description, meaning), the scholar explained the content. The tippani (gloss) followed with an analysis of challenging terms or phrases.

It is against the background of Cumaratunga's Hela Havula movement that Tennakoon's first poetic work, Vavuluva (Bat language, 1939), holds significance. It was a long narrative poem that comprised 551 quatrains. Because Cumaratunga was enamored with this poem, he wrote a long introduction to Vavuluva that analyzed the work's aesthetics and characters. Cumaratunga claimed that Vavuluva could win a Nobel Prize if translated into English. ${ }^{37}$

One may conclude that Tennakoon wrote Vavuluva for two principal reasons. The first was to rewrite anti-Sri Lankan scenes in the Indian Ramayana epic. This becomes evident when one considers the narrative of the poem. Vavuluva revolved around a conversation between a male bat, Vavula, and female drongo bird, Käviḍiya. Tennakoon may have gravitated toward fables because Cumaratunga had used anthropomorphic animal characters to criticize society in his fable-like Magul Käma (The wedding feast) and Hin Säraya (The subtle attack). ${ }^{38}$

Both Vavula and Kävidịya have a long Sinhalese ancestry that they trace back to ancient tribes in India and Sri Lanka. The two meet in the evening, when Kävidiya's husband is late to return home (vv. 1-21). After Käviḍiya tells Vavula about her distinguished family lineage (vv. 22-45), Vavula reveals that one of his ancestors lived in the castle garden of Sita's father (Sita is the heroine of the Ramayana). This ancestor was later exiled to the south of India, where Rama (the hero of the Ramayana) and Lakshmana (Rama's brother) lived (vv. 55-59).

Readers of Vavuluva gained a different perspective on two Sri Lankan characters of the Ramayana: Ravana and his sister Surpanakha. Tennakoon attempted to redeem Surpanakha's character. In the standard version of Valmiki's Ramayana, Ravana's sister Surpanakha is an evil woman who attempts to seduce Rama and his brother Lakshmana. After the brothers reject Surpanakha's advances, she attempts to kill Sita, but Lakshmana cuts off her ears and nose. Conversely, in Vavuluva, Surpanakha is a "beautiful" (rümat, v. 61) and "friendly woman" (yeheliyak, v. 64). She does not flirt with Rama and Lakshmana; they crudely speak to her (vv. 65-70).

Tennakoon also tried to redeem the character of Ravana. In the standard $R a$ mayana, Ravana tricks Rama and Lakshmana, abducts Sita to Sri Lanka, and demands she marry him. In Tennakoon's Valuvuva, Sita wants to go to Sri Lanka to meet Ravana, the great king of Sri Lanka (v. 78). When she is in Sri Lanka, Ravana valiantly protects her (vv. 110-24)..$^{39}$

The second reason Tennakoon seems to have written Vavuluva was to criticize and satirize the Royal Asiatic Society's Sinhala dictionary project, especially their 
hire of linguist Wilhelm Geiger. ${ }^{40}$ The very title of the poem was a humorous allusion to this project. To create the word "Vavuluva" Tennakoon combined the Sinhala word for bat (vavula) with the suffix -uva. The suffix -uva is found in the word eluva, which designates "pure or ancient Sinhala language." By combining vavula and $u v a$, Tennakoon meant to convey the meaning "bat language." ${ }^{41}$

One year before Tennakoon published Vavuluva, the German linguist Wilhelm Geiger published A Grammar of the Sinhala Language (1938). The Sinhalese intelligentsia knew of Geiger because of earlier seminal articles he published about etymologies of roughly two thousand Sinhala words $(1896,1897)$. The Sinhalese intelligentsia, except for the members of the Hela Havula, had accepted Geiger's argument that the Sinhalese language had Indo-Aryan origins. ${ }^{42}$

Geiger and the dictionary's chief editor, Sir D. B. Jayatilake, had launched the dictionary project in 1926. It progressed at a snail's pace: part 1 of the first volume was published in 1935. The slow pace prompted Cumaratunga to publish a public letter in the Helio, the English-language journal of the Hela Havula. Cumaratunga volunteered his services to complete the dictionary in two years..$^{43} \mathrm{He}$ was frustrated because the dictionary project was put under the guidance of Geiger, a foreign scholar who he felt sorely lacked in Sinhala fluency. To vent his frustration, Cumaratunga authored thirteen sardonic letters of criticism, published in both Sinhala and English, about Geiger's A Grammar of the Sinhala Language. In the ninth criticism, Cumaratunga attacked the credibility of Geiger's work and the new field of comparative philology. Geiger, Cumaratunga wrote, did not even know the basic pronouns in Sinhala:

To Prof. Geiger $\approx$ [ [ē] and $\odot 3)^{\prime}$ [hē] means "he" "she" or "it." This must indeed have come as a result of some mysterious and rigid process of highly "scientific" research. ๑ [o] and ๑3 [hē] in Sinhala is equal to "she" in English! It will be ridiculous to argue to the contrary. One who knows the Sinhala language will require no argument at all to be convinced that it is absolutely untrue to say that $\approx[\bar{e}]$ and $\odot{ }^{\circ}[$ hē] means "she," and those whose limited knowledge of Sinhalese requires the thick cover "Comparative Philology" to protect it from the atmosphere, will never come out of their fortified shelter to face any kind of argument. ${ }^{44}$

In addition to these criticisms, Cumaratunga authored in English three "Open Appeals" in the Hela Havula journal Subasa to Sir D. B. Jayatilake as well as to the chair of the dictionary managing committee and the minister of education. In his appeal to the chair he wrote,

Professor Geiger, the Great Authority of the Dictionary, does not know Sinhalese. His great Grammar, produced with the help of Mr. Julius de Lanerolle, clearly shows how lamentably defective his knowledge of Comparative Philology is so far at least as it deals with the Sinhalese language. A Dictionary compiled under the direction of such a doubtful authority can hardly be satisfactory however long may be the period it takes to materialize. 
To one who is already well-versed in the language, who needs not run from this end to the other end of the island to learn the etymology of one small word, who need not make a forced display of his erudition by coming out in the public over and over again with the etymology of a single word, that too unearthed by someone else, two years is quite ample to complete the most comprehensive Sinhalese Dictionary. ${ }^{45}$

In the twenty-seventh chapter of Vavuluva Tennakoon lampooned the dictionary project and sought to discredit Geiger's scholarship on the Sinhala language:

Chapter 27. The Arrangement of the Bat-Language Dictionary

[Vavula:] The assembly gathered

To protect the Buddhist order

But commenced [instead]

The compilation of the Bat-language dictionary

Everyone in the group

Examined the state of Bat-language

And then entrusted

The job of remedying the language to me.

Therefore, on the following day

I brought together

All the Bat-language books

And all the scholars of those books.

My head was like the handle of a manual drill.

It turned in one direction when reading these books,

And in jerked in another when confronted

With what scholars said about these works. (vv. 466-69) ${ }^{46}$

Jayanta Weerasekara's commentary on stanza 469 sheds light on the meaning of the phrase "head like a manual drill": "Glossary: 1. burumayeka mița vilasin: "burumaya' is a manual machine to drill wood. To penetrate the wood one turns the handle of the drill in one direction and then in another. Tennakoon says that Vavula's head is like the motion of the handle of this manual drill. When Vavula reads books in the Bat-Language his mind and head move in a focused direction. Yet, when he reads the discourse of scholars on these works his head jerks in another direction [because he is outraged at what they say]." ${ }^{7}$ Tennakoon's intention, then, was to wryly criticize foreign scholarship written about the Sinhala language, like Geiger's etymological studies, because Tennakoon believed these studies spread misinformation about the Sinhala language..$^{4}$

It seems most likely that the character of the bat in Vavuluva was a satirical portrayal of the dictionary's chief editor, Sir D. B. Jayatilake, or at least of the members of the dictionary project who chose a foreign over a native scholar. As Jayanta Weerasekara's commentary for Vavuluva in stanzas 513-14 disclosed: “These two 
stanzas reveal a surprising character trait of Vavula. He does not wish for his neighbors' help as long as he is alive. However talented his neighbors are he does not like to consult them. But he happily takes help from people from far away." ${ }^{49}$ Cumaratunga echoed this sentiment in his introduction to Vavuluva: "Käviḍiya inquires about Vavula's journey to Bintenne: 'Why Bintenne? Can't you learn about your own language from your own people?' No, no. Vavula likes to get help from foreigners much more than from his fellow countrymen. .. Should not the fact that local scholars are willing to give help from the bottom of their hearts influence the bat to accept their offers? Alas, Vavula likes to worship foreigners . . . and would rather die than seek assistance from local scholars to complete a dictionary." 50

\section{PURISM AND THE MUSICAL SPHERE}

Munidasa Cumaratunga did not only inspire poets. Cumaratunga also filled one songwriter with the desire to compose song that would make the members of the Hela Havula proud. In 1934 Rabindranath Tagore staged his opera Shapmochan (Curse redeemed) in Sri Lanka to critical acclaim. Inspired, a young Sinhalese Catholic teacher of music and drama named Baddeliyanage Joseph John persuaded his brother for a loan to study music at Tagore's school, Santiniketan. Joseph John raised more money by staging a performance of a Sinhala-language adaptation of Shakespeare's Hamlet. In 1939 he traveled to Bengal to commence his studies.

He trained for a year in North Indian classical voice, sitar, and orchestration and in Tagore's musical genre known as rabindrasangit. Joseph John then decided to pursue a more rigorous study of North Indian classical music. He secured financial aid from the Ceylon government and traveled to Lucknow to focus on Hindustani voice and sitar at the prestigious Marris College of Music. ${ }^{51}$

In the mid-twentieth century many Sinhalese Christians changed their anglicized names to Sinhala names. Around 1940 Joseph John adopted the stage name of "Sunil Shanti." 52 He later adjusted his name to "Sunil Santha." In 1944 he scored the highest marks in the first division sitar class, completed a bachelor's degree in music, and returned to Sri Lanka. The principal of the Marris College of Music, S. N. Ratanjankar, authored a letter of recommendation on behalf of Santha.

Back home, Santha's uncle, Father Moses Perera, gave Santha a temporary place to lodge. Father Perera was a member of the Hela Havula. He introduced Santha to Cumaratunga's writings. Santha began to feel that Indian music prevented Sri Lankan composers from creating a national musical genre.

Santha wrote this about his experience reading Munidasa Cumaratunga:

While in North India I transformed into a North Indian in my dress, language, customs, ideas, and every other facet. ... Even when I was back in Sri Lanka, I behaved as though I were still in North India. I felt proud to forget all my Sinhalese ways and 
act like this. When singing Sinhala songs, I would pronounce the words as though they were Hindi words. I considered the Hindi accenting of Sinhala words to be a great thing. In short, in every single activity I pushed my Sinhalese identity away and brought forward North Indian ways of being.

One day I directed my attention to a few Sinhala verses. I read them once, twice, and a third time. I knew the verses contained an important idea. . . I felt transformed within. The stanzas that really penetrated my heart are these:

"On account of my country and nation

If I were I to go to war and kill enemies

And lose my life thereof

Will not my glory live for a hundred years?

If one lives confined in a stone cave

His life and name will never last

Sacrifice that life to the country and nation

Preserve your honor and remain undefeated

May I never see a Helaya [a Sinhalese person]

Two-footed but not doing any service

Working earnestly for the good of country and nation

Forget life's cravings for a moment" 53

Santha read these three stanzas in Cumaratunga's Hela Miyäsiya and felt purified of what he called his "Hindustani-ness": "I searched for other writings penned by this meritorious hand [Munidasa Cumaratunga]. Having found them, I read with great pleasure. This writer was successful in destroying all my useless ideas. I turned in a completely different direction. I felt that my 'Hindustani-ness' left me and went all the way back to India for good. Today there is nothing more important than my language, nation, and country. ${ }^{54}$ Transformed, Santha now espoused Cumaratunga's motto of "language, nation, country" (basa, desa, räsa).

The earliest reference one finds in regard to Santha's active involvement in the Hela Havula may be March 2, 1946. That day Santha sang the commemoration song at the ceremony for the second death anniversary of Cumaratunga. Santha had set a melody to a poem titled "Cumāratungu Samaru Gīya" (Cumaratunga commemoration song), composed by Hela Havula poet Amarasiri Gunavadu. The poem resisted easy comprehension due to its purist poetic lexicon. Consider this translation:

He had a might of intellect and devoted his life to the Triple Gem

He thrilled the hearts of all and made formidable enemies into cotton that wafts in the air

He showed the way of great seers, this God of Hela, our "Gem" Munidasa Cumaratunga

We will put your advice to use without rest and commemorate you every day ${ }^{55}$ 
Here, the "triple gems" again referred to Cumaratunga's slogan of "language, nation, country."

\section{SANTHA'S “ŌLU PIPİLĀ," LITERARY GRAMMAR, AND MUSICAL STYLE}

In 1946 Santha released his breakthrough hit "Ōlu Pipīlä" (The lilies have blossomed). He composed the lyrics and music and performed as the solo vocalist. The song became the first song that the Sri Lankan radio station Radio Ceylon, recorded onto a record. ${ }^{56}$ "Ōlu Pipīlā" told a story about a young man courting a girl, Mala, near a village pond.

O sister, the lilies, whiter than white, have blossomed and sway in the field

O sister, fair-skinned maiden, shall I pluck them and weave a flower garland for you?

Come in the water Mala and give me your hand

We'll cut the flowers, weave garlands, and adorn ourselves ${ }^{57}$

Santha's lyrics evoked a lush village scene through the usage of definite articles, such as chains of künis fish and swaying white lotus flowers. He placed the refrain in the last line of each stanza: "We'll cut the flowers, weave garlands, and adorn ourselves":

O sister, the unbroken chains of fish play lovingly

O sister, the kūnis fish go jumping as if we have called them

Mala, here is the flower I picked for you. This one is yours.

We'll cut the flowers, weave garlands, and adorn ourselves

O sister, I am ashamed to be defeated by your hands

O sister, don't be in such a rush, let's wade slowly in the water and pick lily flowers

Mala, with the whiteness of the flowers on your body, you become more stunning

We'll cut the flowers, weave garlands, and adorn ourselves

O sister, we have plucked and picked and now the flowers are heavy in our hands

O sister, let's go put them on the top of the mountain

Mala, your younger brother is coming, let's go quickly

We'll cut the flowers, weave garlands, and adorn ourselves ${ }^{58}$

The poetic quality of the song text in "Ōlu Pipilā" could be said to reside in the lexical and phonemic parallelism. Take the famous first stanza and consider the careful attention Santha gave to repetition, assonance, and alliteration: 
ōlu pipīlā vela lẹ̣a denavā sudaṭa sudē naňgō

ōlu neḷālā māla gotālā denna da sudu naňgō

ennä diyē bäsä mā hā dennä obē ata mālā

ōlu neḷālā māla gotālā palaňdimu api mālā

At the start of lines 1, 2, and 4, Santha uses the word ólu (lilies). He places the word nañgo (sister) at the end of the first two lines. In lines 2 and 4 , he repeats the entire phrase of òlu nẹlạlā màla gotālā (weave lotus and make garlands). He also employs vowel assonance in vela lela denavā (shaking in the pond), nelālà māla gotāla (weave and make garlands), and in the third line:

ennä diyē bäsä mā hā

dennä obē ata mālā

Cumaratunga, one may infer, would have approved of the way Santha's song text in "Ōlu Pipīlā" employed subject-object agreement found in literary Sinhala. Cumaratunga had believed that standardizing a more literary grammar was an essential requirement for a śișta, or "cultured" society. Cumaratunga, Sandagomi Coperahewa writes, "used metaphors of law and society to define the relationship of grammar to language." ${ }_{59}$ Consider this revealing statement made by Cumaratunga in 1938: "Just like a society without laws, a language without laws will plunge into confusion. The Sinhala language is facing a disaster. A course of action to prevent this is immediately called for. ... [A standardized] grammar is utterly necessary for a cultured society." 60

Taking these campaigns to heart, Santha employed in "Ōlu Pipīlā" the rare future tense (neuter/masculine and plural) suffix, -o (-๑), for conjugating the verb root yana (go) into "yannō." ${ }^{1}$

Kūnissō uḍa pänä pänä yannō apa kändavā naňgō [Sister, the kunisso fish go jumping as if they have called us] $]^{62}$

One finds another rare future-tense conjugation in Santha's song "Haňda Pānē" (In the moonlight, 1947). He used the feminine future-tense suffix, $-\bar{\imath}(\%)$, for conjugating the root näla- (to be lulled, to sway) into "nälävenn $\bar{\imath}$."

ambiliyō kiyamin nälävennī [She sways back and forth, singing, O Moon! $]^{63}$

As with the previous example, this was a literary form that lyricists tended to not include in gramophone or radio songs. In addition, Santha, like the Hela Havula poets, added an ä-kāraya letter to words like pänä pänä (go jumping), nälävennī (she sways), and bäbälena (shining), which gave his lyrics a pure-Sinhala touch.

Santha believed that his song lyrics with proper literary grammar could put the Sinhalese English-educated elite back in touch with their mother tongue. In the introduction to his songbook Sunil Handa (Sunil's voice, 1947), he remarked, 


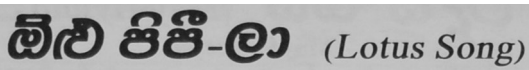
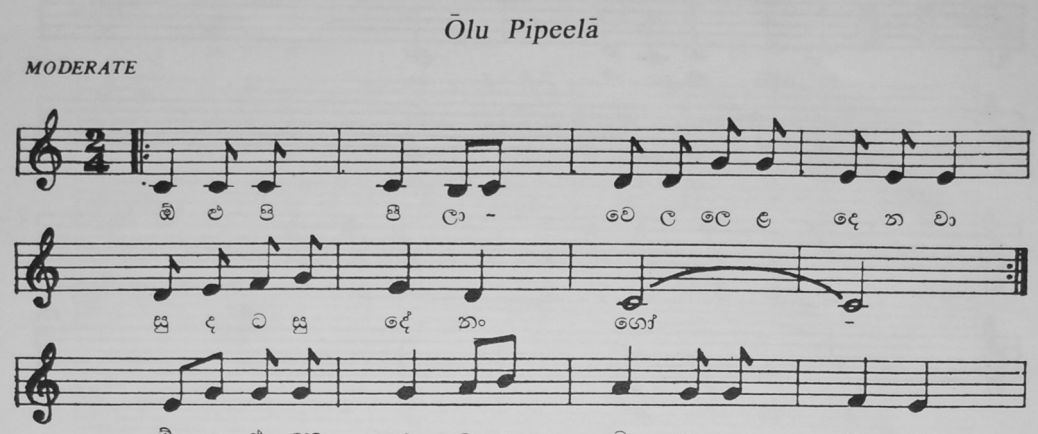

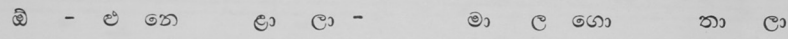

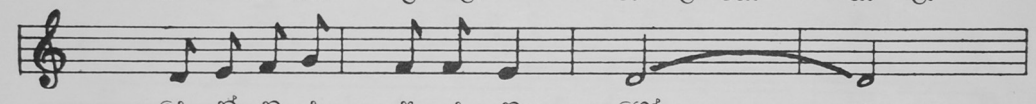

बद्ध का का द ध है ऊ० बजा
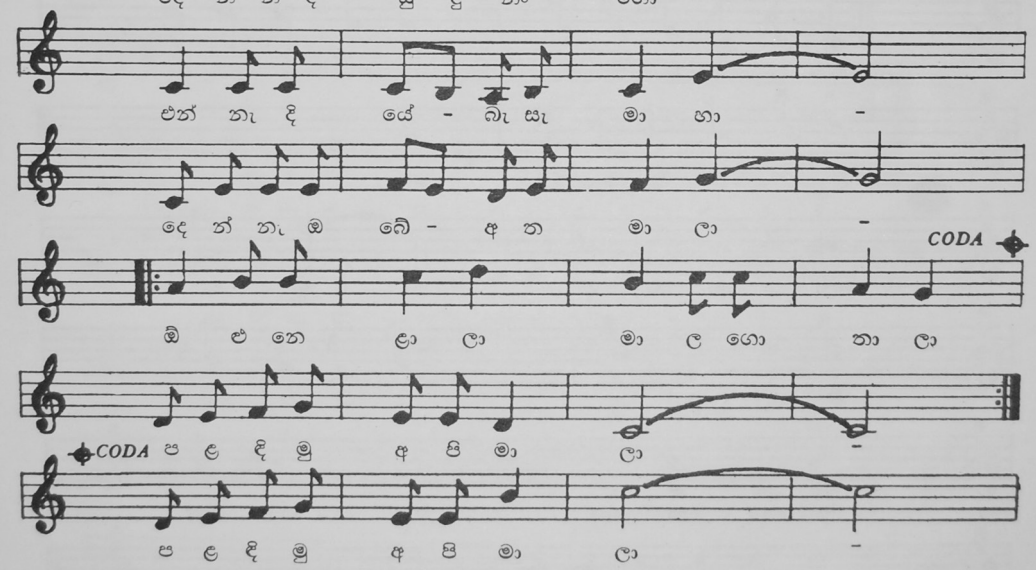

ALL RIGHTS RESERVED

FIgURE 3. Sunil Santha’s “Ōlu Pipeelā," in Sunil Santha: Song Folio (Rajagiriya: Santha, 1948), 3. Courtesy of Lanka Santha.

Those assimilated to Western food and drink, clothing, customs and habits, etc., have driven our language into the kitchen. These people are ashamed to talk in their mother tongue. ... Some of them joke and say, "This is Sinhalese music." They then start to imitate päl kavi [hut poetry], karatta kavi [cart poetry], sivpada [sung quatrains], and vannama. . . I find our current situation quite upsetting. This is why I brought out [my first songbook] Ridī Valāva. Must I say anything about the service I have rendered through the songs like "Ōlu Pipīlā" and "Haňda Pāne"? Those who gagged from distaste from the Sinhala language and gave prominence to English now happily sing these lyrics. Now they will familiarize themselves with songs in their mother tongue. This is one of the goals of my new music. ${ }^{64}$ 
He would later print two songbooks with English titles-Sunil Santha Song Folio (1948) and Song of Lanka (1950) — especially for the Westernized Sinhalese elite in Colombo. Because many members of high society had studied Western classical music, Santha transcribed the songs in Western notation. Instead of transliterating his songs into English script, he printed Sinhala script under the notation (fig. 3). It is striking to note how he used Western notation to appeal to the tastes of this class, yet simultaneously refamiliarized them with "songs in their mother tongue" by using the Sinhala script rather than a transliteration.

Just as Cumaratunga sought to remove North Indian influence from the Sinhala language, Santha greatly rid his songs of North Indian musical influences. ${ }^{65}$ In his book Désiya Sangita (National music), Santha lashed out against Sinhalese musicians who sang Hindustani music. He contemptuously labeled them Sinhalastankārayō, or "'Sinhalastan' [Sinhalese + Hindustan] crowd": "There is a reason why [Sri Lankan] national music and music education is bitter like a poisonous kaduru nut. There is a reason why everyone who trains in Indian classical music transforms into a Hindustani person and feels that our national music should be Hindustani music: these people have no affection, consideration, or love for their language, nation, or country." 66

Santha had studied classical Indian vocal music and scored the highest marks in the first division sitar class at Marris College. Yet his music had a marked absence of Indian musical ornamentation. Sunil Ariyaratne emphasizes the influence of Santha's Catholic upbringing on his musical style: "Sunil Santha's voice was trained from childhood in Catholic music of the Church. . . . His voice sounded new to Sinhala music connoisseurs. It was uniquely different from vocalists like Sadiris de Silva, H. W. Rupasinghe, Don Manis Pattiarachche, N. Romlas de Silva, and even Ananda Samarakoon. These musicians who trained in North India used all the ornamentations like kan svara and meend found in Hindustani classical music. ... Sunil Santha rarely used these ornamentations. He moved straight from note to note. He also pronounced the words better than the other Sinhalese musicians who trained in North India." ${ }^{67}$ D. P. M. Weerakkody, however, stresses the impact of Cumaratunga: "Sunil Santha was influenced not only by Cumaratunga's linguistic style and philosophy but also Cumaratunga's views on music. Although at a later date Santha criticized the limitations of Cumaratunga's Hela Mìäsiya, initially the book appears to have made some impact on Santha. According to Jayantha Aravinda. ... This impact explains the simplicity of many of Sunil Santha's melodies and the predominance of natural [unornamented] notes in them." 68

Santha's compositions may also be said to typify what ethnomusicologist Thomas Turino has termed "modernist reform": reform of local arts based on "cosmopolitan" aesthetics, ethics, and worldviews. ${ }^{69}$ Modernist reform describes the way in which musicians must maintain a unique local identity on the international scene. Santha's songs, very popular among the Sinhalese English-educated 
elite, also appealed to the British on the island, because of his song's Western harmonies and catchy melodies. For example, Joan Eleanor Ramsbotham, daughter of the Ceylon governor general Herwald Ramsbotham, praised Santha's songs "Ōlu Pipîlā," "Kōkile Nāde" (The cuckoo bird's song), and "Haňda Pānē" in a personal letter sent to Santha in June $1951 .{ }^{70}$ If we succinctly describe Santha's early compositional style, it would be that he set simple yet clever and catchy melodies based in Western harmonies to poetic Sinhala song texts..$^{71}$ These melodies are predominantly written in the major scale, accompanied by I, IV, and V harmonies set in $4 / 4$ meters and performed by the upright bass and acoustic guitar.

\section{SANTHA AND TENNAKOON'S “DUDAN'ODA BIŇDA”}

Santha's Cumaratunga-style rejection of North Indian influences caused a controversy in 1952. In April Radio Ceylon rehired S. N. Ratanjankar-Santha’s former principal at the Marris College of Music - to audition and grade Sinhalese musicians for radio posts. Ratanjankar had already visited the island once to audition musicians in $1949 .{ }^{72}$ Santha boycotted the 1952 auditions and later controversially quit his post as an A-grade musician. During this time he wrote in protest to the Lankādipa newspaper. In one article Santha expressed anger at station officials who refused to support local talent. Santha's complaints were similar to those that Tennakoon made in Vavuluva with regard to the officials who refused to hire Cumaratunga to edit the Sinhala dictionary. Santha felt that hiring Ratanjankar was a repeat of the Geiger controversy that Tennakoon lampooned in the final chapter of Vavuluva. Santha argued, "I do not believe that we should wish for a foreigner to come to Sri Lanka to advise us on how to create a national music just because we brought a German to advise us on the Sinhala language." 73

By this time Santha and Rapiyel Tennakoon had released their new song, "Dudanoda Biňda" (Kill this cruel creep). Tennakoon had originally published the text in the second chapter of his second long poem Hävilla. In the poem Tennakoon narrated the plight of a helpless village woman and satirized her fanatical religious practices. In the second chapter a thief steals the hens of the poor village woman, leaving her unable to earn a living. She makes a pilgrimage to the town of Kataragama and curses the man. She pleads with the god Kataragama to avenge the crime and destroy the criminal. Santha set music to this emotional scene.

Tennakoon's poetic verses from Hävilla are found in every compilation of modern Sinhala poetry that I have come across. One reason for the poem's popularity is that Tennakoon fashioned a unique poetic meter that oscillated between quatrains of six and twelve mātrā (syllabic instants). Another reason for the poem's success is the way it teemed with rhyme and alliteration, particularly with the dayanna letter "द" (/d/), which I have set in bold font in the transliteration. These poetics helped 
to intensify the woman's feelings of desperation, hatred for the man that destroyed her livelihood, and devotion to the god Kataragama.

\author{
du da no'da biňda \\ baňda teda kaňda \\ kaňda dev rada \\ sāminē
}

mage kukulā näsū ekā

dadaya obage pālu yakā

tava eka buda dinak takā

innața iḍa no dī makā

[Kill this cruel creep

O splendorous wondrous

King, Lord

Kataragama!

This bugger has destroyed my hens

And plundered your totem.

Destroy him before

Next Wednesday's worship] ${ }^{74}$

In the judgment of composer W. D. Amaradeva, Santha's music and pronunciation of Tennakoon's poetry further heightened Tennakoon's depiction of the woman's desperation, hatred, and devotion:

Santha was able to transform Tennakoon's poem into a song of the highest level because he expertly utilized the medium of music. He infused into music the sounds like cursing, pleading, and crying that we hear in village settings. ... His composition possesses national features distinct from the popular Indian way of singing. ... [One can hear how Santha] gives extra emphasis to pronouncing the dayanna letter. He does so to evoke the woman's resolute state of mind and her abhorrence of the thief. After these three lines Santha composes music for the word "sāminē" that conjures a pleading woman making a vow to the deity of Kataragama with the highest humility and devotion. ${ }^{75}$

In the opening phrase Santha accommodates Tennakoon's alliteration of (mostly) three dayanna letters per poetic line, with melodic motives of mainly three repeated notes (BF\#F\#, EEE, D\#D\#D\#, C\#C\#C, BBB) (ex. 2).

EXAMPLE 2. Three-note motives and three dayanna letters in Sunil Santha and Rapiyel Tennakoon's "Dudan’oda Biňda."

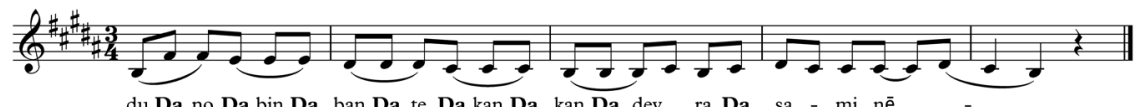

du Da no Da bin Da ban Da te Da kan Da kan Da dev_ ra Da sa - mi nē 
In a revealing statement about his inspiration for the song's music, Santha criticized S. N. Ratanjankar's credibility as Radio Ceylon's music consultant. Because Ratanjankar had not resided in the village areas in Sri Lanka, Santha argued that Ratanjankar lacked in an intimate knowledge of the people's lives and behaviors and was thus not qualified to audition Sinhalese musicians for radio positions:

I am accustomed to experiencing our village women's behavior when they lose something valuable. They curse the gods and take vows. I have often heard them raising their hands and saying in a thundering voice, things like "Oh God of Kataragama! Please just cut this criminals neck off!" When I was setting music to the poem "Kukulu Hävilla" ... I followed the rhythm of this woman's plea.*

* I do not know whether S. N. Ratanjankar has heard our woman's cries, laments, and curses. ${ }^{76}$

To conclude, Cumaratunga and his followers, such as Tennakoon and Santha, constructed an alternative nationalist identity: one based on linguistic purism, opposed to the Arya-Sinhala interpretation of the Mahāvamsa, and hostile toward North India. If John De Silva and his colleagues (chapter 1) created an inner domain of song with Buddhism and North Indian classical music at the core and the West threatening from outside, Cumaratunga and his brothers in the Hela Havula created an inner domain of song and poetry with a pure Sinhala language at the heart and North India threatening from outside.

Santha's radio song and Tennakoon's poetry thus oblige us to rethink Partha Chatterjee's assertion that colonial-era South Asian nationalism "launches its most powerful, creative and historically significant project-to fashion a 'modern' national culture that is nevertheless not Western." ${ }^{\prime 7}$ Chatterjee assumes that there existed only two players in the development of South Asian cultural nationalism: the East and the West. I have tried to illuminate in this chapter how Santha's music turns Chatterjee's contention inside out: Santha used Western musical influences to fashion a modern Sinhalese national music that was not North Indian. 